\title{
9. Deviant Domesticities and Sexualised Childhoods: Prostitutes, Eunuchs and the Limits of the State Child "Rescue" Mission in Colonial India
}

\author{
Jessica Hinchy \\ Nanyang Technological University, Singapore
}

\section{Introduction}

In the late 1860s and early 1870s, colonial officials in north India argued that the British government had a duty to "rescue" girls and boys who were allegedly kidnapped and condemned to a "life of infamy" by eunuchs and women labelled prostitutes. Colonial officials claimed that prostitutes and eunuchs sexually "corrupted" girls and boys, respectively, and hired them out as child prostitutes. British administrators proposed to register and remove children who resided with prostitutes and eunuchs and to appoint "respectable" guardians. In India, unlike Australia, the removal of children was not a general technique of colonial governance. ${ }^{1}$ These projects for the removal and reform of children who lived in brothels and with eunuchs were thus somewhat unusual colonial attempts at child rescue. ${ }^{2}$

The singular English-language colonial category of "eunuch" was internally diverse and encompassed a multiplicity of social roles. The term eunuch could be used to variously encapsulate male-identified and female-identified, emasculated and non-emasculated, socially elite and subaltern, politically powerful and relatively politically insignificant groups. The hijra community

\footnotetext{
1 Satadru Sen, Colonial Childhoods: The Juvenile Periphery of India, 1850-1945, London: Anthem Press, 2005, p. 57.

2 The research for this paper was conducted at several archives in India, including the National Archives of India (NAI) in Delhi and the Uttar Pradesh State Archives (UPSA) branches in Lucknow and Allahabad. At the Allahabad branch of the Uttar Pradesh State Archives I was able to access district-level records on the implementation of the Criminal Tribes Act, Part II, against the hijra community, including the reports of local police intelligence and district registers of eunuchs' personal details and property. I also accessed the British Library (BL), London, India Office Records (IOR). Archival work for this paper was conducted as part of the author's Ph.D. project at The Australian National University, Canberra, and was partly funded by an Endeavour Australia Cheung Kong Research Fellowship, awarded by the Australian Government.
} 
was the focus of colonial concern in the nineteenth century and is the focus of this chapter. Hijras are a group of male-born emasculates or "born eunuchs"3 who wear feminine clothing, adopt feminine names, ${ }^{4}$ are associated with a power to bless or curse fertility, and perform in public and in households following births. Yet the British also classified several additional groups as "eunuchs," some of whom were not in fact emasculated including: the khwajasarai, maleidentified court officials and attendants of the female quarters who were slaves but could nonetheless rise to positions of political prominence; and the zanana, "effeminate men" who were not emasculated, often dressed as women, performed in public, and usually lived with biological and/or affinal kin. ${ }^{5}$ Throughout the nineteenth century, the boundaries of the internally diverse colonial category of eunuch repeatedly shifted as colonial officials disagreed on the classification of particular Indian social roles.

The colonial category of "prostitute" was similarly ambiguous. Prostitute was often used by colonial officials to describe a range of social roles for women outside of conjugal domesticity. These groups included: courtesans, or the ta'waif, who were highly educated, considered experts on social etiquette, and were often talented performers; ${ }^{6}$ the devadasi, who were dedicated to a Hindu temple, symbolically married to a deity, performed ritual functions, and sometimes formed long-term sexual relationships with their benefactors; ${ }^{7}$ and women who worked in brothels or kotha (brothels and courtesan establishments), who were usually of lower socio-economic status. ${ }^{8}$ When the colonial government sought to regulate prostitution, for instance through the registration and

3 Many registered eunuchs described themselves as "born eunuchs" to colonial officials. S.A. Campbell, Officiating Superintendent of Police, Bulandshahr, "Register of eunuchs in the district of Boolundshuhur coming under Section 24 of Act XXVII of 1871," 6 January 1873, Uttar Pradesh State Archives (UPSA), Allahabad, COM/29/8.

4 In the North-Western Provinces and Oudh, an area of northern India that is comprised of the modern states of Uttar Pradesh and Uttarakhand, hijras adopted feminine names, although in the nearby Punjab they apparently kept masculine names. William Crooke, The Tribes and Castes of the North-Western Provinces and Oudh, vol. 1, Calcutta: Office of the Superintendent of Government Printing, India, 1896, p. 495; H.A. Rose, A Glossary of the Tribes and Castes of the Punjab and North-West Frontier Province, Lahore: The Civil and Military Gazette Press, 1911, p. 331. This difference in naming practices has continued into the postcolonial period. Kira Hall and Veronica O'Donovan, "Shifting gender positions among Hindi-speaking hijras," in Rethinking Language and Gender Research: Theory and Practice, ed. Victoria Lee Bergvall, Janet Muelle Bing and Alice F. Freed, London: Longman, 1996, pp. 228-66, p. 247.

5 Somewhat confusingly, the Hindi/Urdu word zanana can refer to both the female quarters of households and to effeminate men.

6 On ta'waif see Veena Talwar Oldenburg, The Making of Colonial Lucknow: 1856-1877, Princeton: Princeton University Press, 1894; Veena Talwar Oldenburg, "Lifestyle as resistance: the case of the courtesans of Lucknow, India," Feminist Studies 16(2) (Summer 1990): 259-87.

7 On devadasi see Mytheli Sreenivas, "Creating conjugal subjects: devadasis and the politics of marriage in colonial Madras presidency," Feminist Studies 37(1) (Spring 2011): 63-92; Kunal M. Parker, “'A corporation of superior prostitutes': Anglo-Indian legal conceptions of temple dancing girls, 1800-1914," Modern Asian Studies 32(3) (1998): 559-633. Also see Annie McCarthy, "Agency and salvation in Christian child rescue in colonial India: Preena and Amy Carmichael," this volume.

8 See especially Ashwini Tambe, Codes of Misconduct: Regulating Prostitution in Colonial Bombay, New Delhi: Zubaan, 2009. 
forced medical inspection of prostitutes under the 1864 Cantonment Acts and the 1868 Contagious Diseases Act, colonial officials debated which social roles could be defined as prostitutes. ${ }^{9}$ Though colonial officials often disagreed on the boundaries of the prostitute category, they sometimes labelled all Indian women not confined to "respectable" domesticity as prostitutes, claiming that it was often impossible to distinguish prostitutes from "common" or low-caste Indian women and suggesting these were overlapping categories.

The proposal to remove children from hijra households eventuated in Part II of the Criminal Tribes Act (CTA) of $1871 .^{10}$ This law provided for the registration of eunuchs who were considered "reasonably suspected" of kidnapping, emasculation and sodomy. ${ }^{11}$ For colonial administrators, hijras were the archetypal "suspicious eunuch." The registration of eunuchs was implemented in a single province in north India, the North-Western Provinces (NWP). ${ }^{12}$ Police watched eunuchs and their movements, while eunuchs were prohibited from performing or cross-dressing in public and were denied several civil rights. ${ }^{13}$ All children who resided with eunuchs were removed and eunuchs who "kept" a child were liable to prosecution. British colonial officials claimed this would not only facilitate the reform of children whom the hijra community had "corrupted," but also prevent their emasculation and thus achieve the government's broader agenda of causing hijras to "die out." ${ }^{14}$ Yet less than one hundred children were found with eunuchs, despite the expectations of the colonial government that kidnapping was rife. ${ }^{15}$ Moreover, the proposal to register children who lived with prostitutes never eventuated. The proposed rescue of children in brothels and hijra households is a story of failed plans

9 Kenneth Ballhatchet, Race, Sex and Class Under the Raj: Imperial Attitudes and Policies and Their Critics, 1793-1905, London: Wiedenfield and Nicolson, 1980; Philippa Levine, Prostitution, Race, and Politics: Policing Venereal Disease in the British Empire, London: Routledge, 2003; Judy Whitehead, "Bodies clean and unclean: prostitution, sanitary legislation, and respectable femininity in colonial North India," Gender \& History 7(1) (April 1995): 41-63.

10 "Criminal tribes" were targeted under Part I of the 1871 Criminal Tribes Act, Part II of which was aimed at eunuchs. Act No. XXVII of 1871, BL, London, IOR, V/8/42. See also, Rachel J. Tolen, "Colonizing and transforming the criminal tribesman: the Salvation Army in British India," American Ethnologist 18(1) (February 1991): 106-25, pp. 113-22.

11 Under government policy, a "reasonable suspicion" of kidnapping, castration and sodomy against a eunuch was proved not by criminal convictions, but rather by whether or not the individual cross-dressed or performed in public.

12 The CTA applied to the Punjab, the NWP and Oudh. However, only the NWP government introduced registers across the province. The CTA Part II was enforced in Oudh from 1877 when it joined with the NWP. I will refer to the province as the NWP throughout (including post-1877) to avoid confusion.

13 "An Act for the Registration of Criminal Tribes and Eunuchs," Act No. XXVII of 1871, Passed by the Governor-General of India in Council, British Library (BL), London, India Office Records (IOR), V/8/42.

14 R. Simson, Secretary, NWP, to all Commissioners, NWP, circular no. 32A-434A, 9 June 1865, BL, London, IOR, $\mathrm{P} / 438 / 61$.

15 T. Dennehy, Officiating Deputy Inspector-General of Police, NWP, to Officiating Personal Assistant to Inspector-General of Police, NWP, 15 August 1871, BL, London, IOR, IOR/P/92. 
and small experiments. Yet this case study highlights the tensions and limits of government-directed child rescue projects in colonial India and illuminates the relationship between the colonial government and the missionary project.

This chapter is motivated by three questions. First, what do proposals to rescue children in kothas and hijra households tell us about the colonial disciplining of domestic arrangements and childhoods in India? I argue that the proposed colonial regulation of prostitute and hijra domestic spaces reveals the fissures and limits of the colonial child-rescue project. The proposed removal of children from kothas and hijra households exposed the areas of overlap, and lines of tension between, the missionary project and the colonial administration. Although Christian ideologies often underpinned colonial government interventions into Indian childhoods and domestic arrangements, missionarygovernment cooperation was limited in practice. Moreover, different levels of the colonial administration came into conflict on the question of whether the reform of Indian children perceived to be sexually "corrupted" was possible, was a moral imperative and should be an administrative priority. Child rescue discourses underpinned by evangelism had limited sway amongst many British administrators.

In practice, the colonial administration circumscribed or abandoned interventions into the lives of Indian children perceived as sexually corrupted when this did not accord with broader policy priorities. The proposal to remove girls from brothels was defeated due to the practical difficulties this would involve and because the colonial government was invested in the existence of regulated prostitution. In the early 1870s, the discussion in colonial official circles of proposals to "save" girls in kothas transformed into a discussion of how best to protect the male clients of underage prostitutes, highlighting the tenuous hold of child rescue discourses in colonial official circles. Although the removal of children from hijra households was enshrined in law in 1871, the stated goal of reforming these boys through moral education was largely abandoned in practice. Instead, the government prioritised the removal of children and their ongoing surveillance to stop any contact with hijras, prevent their emasculation and cause hijras to die out. That is, the agenda of extermination was prioritised over the agenda of reform.

Second, what do colonial interventions into prostitute and hijra domestic arrangements tell us about broader historical transformations in domestic and kinship formations in India? Whereas histories of domesticity in modern India and elsewhere have largely focused on women and constructs of femininityrather than children, childhood, men and masculinity ${ }^{16}$ - this study highlights

16 Swapna Banerjee draws attention to the need to expand the field of domesticity studies "to include men and children." Swapna M. Banerjee, "Debates on domesticity and the position of women in late colonial India," History Compass 8(6) (2010): 455-73, p. 455. 
the significance of notions of childhood to constructs of domesticity. This chapter situates proposals to "rescue" children in the kotha and the hijra household in the context of the colonial and elite Indian privileging of conjugal familial forms and the marginalisation of diverse domestic formations over the eighteenth and nineteenth centuries. I build upon the work of several historians, notably Indrani Chatterjee, who have recently shown the historical diversity of South Asian forms of domestic arrangements and notions of family and kinship, ${ }^{17}$ and specifically highlight the need to broaden our analysis of domesticity to include non-biological kinship. Forms of kinship-making were evident amongst both elite and subaltern social sections in India in the eighteenth and nineteenth centuries. The dominant conceptual framework for non-biological kinship in the anthropological literature is "fictive kinship." 18 However, this concept sets up a dichotomy between "real" and "fictive" kinship that does not account for the importance of kinship-making practices in the lives of both women labelled prostitutes and hijras. Instead, I use the term "constructed kinship"19 to describe kinship-making practices including formal adoption, de facto kinship (performing the social obligations of a relative without formal adoption) and the discursive deployment of kinship terms to describe social relationships.

17 Indrani Chatterjee, "Introduction," in Unfamiliar Relations: Family \& History in South Asia, ed. Indrani Chatterjee, Delhi: Permanent Black, 2004, pp. 1-59, p. 10; Sumit Guha, “The family feud as political resource in eighteenth-century India," in Unfamiliar Relations: Family \& History in South Asia, ed. Indrani Chatterjee, Delhi: Permanent Black, 2004, pp. 73-94; Indrani Chatterjee, "A slave's quest for selfhood in eighteenthcentury Hindustan," Indian Economic and Social History Review 37(1) (2000): 53-86; Michael H. Fisher, "Becoming and making 'family' in Hindustan," in Unfamiliar Relations: Family \& History in South Asia, ed. Indrani Chatterjee, Delhi: Permanent Black, 2004, pp. 95-121; Indrani Chatterjee, Gender, Slavery and Law in Colonial India, New Delhi: Oxford University Press, 1999; Indrani Chatterjee, Forgotten Friends: Monks, Marriages, and Memories of Northeast India, New Delhi: Oxford University Press, 2013.

18 There have been several anthropological studies of non-biological kinship relationships in contemporary India. These studies use the term "fictive kinship," although some anthropologists, such as Helen Lambert, have acknowledged there are problems with this term. Helen Lambert, "Sentiment and substance in North Indian forms of relatedness," in Cultures of Relatedness: New Approaches to the Study of Kinship, ed. Janet Carsten, Cambridge: Cambridge University Press, 2000, pp. 73-89; Helen Lambert, "Village bodies? Reflections on locality, constitution, and affect in Rajasthani Kinship," in Culture, Creation, and Procreation: Concepts of Kinship in South Asian Practice, ed. Monika Böck and Aparna Rao, New York: Berghahn Books, 2000, pp. 81-100; Geert de Neve, “'We are all sondukarar (relatives)!': kinship and its morality in an urban industry of Tamilnadu, South India," Modern Asian Studies 42(1) (2008): 211-46. Also see Douglas Haynes' oral history of textile workers. Douglas E. Haynes, "Just like a family? Recalling the relations of production in the textile industries of Surat and Bhiwandi, 1940-1960," in The Worlds of Indian Industrial Labour, ed. Jonathan P. Parry, Jan Breman and Karin Kapadia, New Delhi: Sage Publications India, 1999, pp. 141-70. Amrita Pande's study of surrogate mothers uses the framework of "everyday forms of kinship" to describe various non-biological and non-affinal kinship relationships, emphasising the "multivocality of kinship" and its openness to "manipulations and transformations," and conceptualising kinship as a "process." I take a similar approach to Pande by emphasising the practices through which kinship relationships are made and maintained. Amrita Pande, "'It may be her eggs but it's my blood': surrogates and everyday forms of kinship in India," Qualitative Sociology 32(4) (2009): 379-97, pp. 387, 393.

19 Akitoshi Shimizu has used also used the term "constructed kinship," although he uses this term to describe "[a]ll states of kinship ... transformed out of kinship-by-procreation," that is, the cultural construction of forms of kinship more broadly (which includes both biological and non-biological kin). Akitoshi Shimizu, “On the notion of kinship," Man 26(3) (September 1991): 377-403, pp. 395-99. 
Constructed kinship relationships are ways of thinking about and describing relationships that are embedded in structures of social meaning and are enacted through practices of kinship-making.

Finally, in this chapter I ask how did marginalised children experience child rescue projects? Through the case study of the removal of children from the hijra community, I foreground the experiences and agency of children. At the same time, I analyse the politics of knowledge production underlining the recording of the stories and actions of children in the official colonial archive. Colonial discourse represented children in the hijra community as either victims who needed saving, or as corrupt and criminal. Yet the colonial archive contains fragments of their lives, which I reconstruct in the latter part of this paper. Moreover, colonial records reveal the ways in which the potential resistance of removed children threatened to subvert colonial agendas. The danger of the agency of children in hijra households - and the possibility that they would return to hijras following their forced removal-pervades official discussions. Most existing historical studies of modern Indian childhoods - for instance, Satadru Sen's excellent history of colonial juvenile reformatories as a site of colonial and nationalist politics ${ }^{20}$ - focus on discourses surrounding children and projects to transform them in desired directions. ${ }^{21}$ However, it is also important to analyse the experiences and agency of children themselves. As in Karen Vallgårda's recent study of missionary schools and Annie McCarthy's chapter in this book. I analyse both the conceptualisation of childhood and the experiences of children. ${ }^{22}$

\section{The historical context}

The proposed removal of children from kothas and hijra households needs to be situated in four interlinked historical contexts: transitions in domestic arrangements and family formations in eighteenth- and nineteenth-century

\footnotetext{
20 Sen, Colonial Childhoods. See also, Satadru Sen, “The orphaned colony: orphanage, child and authority in British India," Indian Economic and Social History Review 44(4) (2007): 463-88.

21 See for instance, Ashwini Tambe, "The state as surrogate parent: legislating nonmarital sex in colonial India, 1911-1929," Journal of the History of Childhood and Youth 2(3) (2009): 393-427; Ishita Pande, "Coming of age: law, sex and childhood in late colonial India," Gender \& History 24(1) (April 2012): 205-30; Padma Anagol-McGinn, "The Age of Consent Act (1891) reconsidered: women's perspectives and participation in the child-marriage controversy in India," South Asia Research 12(2) (1992): 100-18; Tanika Sarkar, "Rhetoric against the age of consent: resisting colonial reason and the death of a child-wife," Economic and Political Weekly 28(36) (September 4, 1993): 1869-78; Manu Bhagavan, Sovereign Spheres: Princes, Education and Empire in Colonial India, New Delhi: Oxford University Press, 2003; Sanjay Srivastava, Constructing PostColonial India: National Character and the Doon School, London: Routledge, 1998.

22 Karen A.A. Vallgårda, "Adam's escape: children and the discordant nature of colonial conversions," Childhood 18(3) (2011): 298-315.
} 
India; colonial interventions into Indian childhoods; the influence of evangelism amongst British colonial administrators; and the colonial concern with kidnapping.

Partha Chatterjee has shown that for the Indian elite, the family, conceptualised as a conjugal and affective unit, was an uncolonised domain where Indian culture could be constructed and defended. ${ }^{23}$ However, recent studies have suggested that the paradigm of the conjugal family obscures the complexities of domestic forms in the early modern and modern periods. Indrani Chatterjee has argued that the presence of large numbers of slaves and servants within the family - and the malleable distinctions between these groups and kin - calls into question the privileging of conjugal forms of family in early modern South Asia. ${ }^{24}$ Moreover, a focus on biological forms of kinship obscures the kinship-making practices of both slaves and non-slaves in eighteenth- and nineteenth-century India. ${ }^{25}$ Non-biological kinship relationships could be as crucial in political and social life as biological or conjugal relationships in the early modern period. ${ }^{26}$

My broader study looks at several groups of eunuchs in north India and their kinship formations. Although this paper focuses on hijras, conflicts over the families of khwajasarai, or harem and court eunuchs, highlight the existence of kinship-making practices amongst relatively elite social actors, as well as marginal groups. In eighteenth- and nineteenth-century Awadh, an Indianruled state that was formerly part of the Mughal Empire, khwajasarais formed networks and family households of non-biological kinship through formal ceremonies and informal or symbolic naming practices with fellow eunuchs, slaves, non-slaves and dependants. ${ }^{27}$ Khwajasarais, though slaves, were

23 Partha Chatterjee, The Nation and its Fragments: Colonial and Postcolonial Histories, Princeton: Princeton University Press, 1993.

24 Chatterjee, "Introduction," pp. 13-14; Indrani Chatterjee, "Renewed and connected histories: slavery and historiography of South Asia," in Slavery \& South Asian History, ed. Indrani Chatterjee and Richard M. Eaton, Bloomington: India University Press, 2006, pp. 17-43, p. 19. On domestic slavery see, Tanika Sarkar, "Bondage in the colonial context," in Chains of Servitude: Bondage and Slavery in India, ed. Utsa Patnaik and Manjari Dingwaney, Madras: Sangam Books, 1985, pp. 197-226, pp. 100-06.

25 Chatterjee, Gender, Slavery and Law, pp. 36-57; Chatterjee, "A slave's quest"; Chatterjee and Guha, "Slave-queen, waif-prince."

26 On the political importance of family more broadly, including the symbolic deployment of kinship and adoption, see Guha, "The family feud"; Fisher, "Making family." On eunuchs' kinship-making practices in Murshidabad in Bengal, see Chatterjee, Gender, Slavery and Law, pp. 48-57.

27 One of the most important sources on khwajasarais in Awadh is Faiz Bakhsh's Persian memoir Tarikh Fakakhbaksh, which William Hoey translated as Memoirs of Delhi and Faizabad in 1888-89, which describes at length the relationships between prominent khwajasarais, their masters, kin and dependents. Muhammad Faiz Bakhsh, Memoirs of Delhi and Faizábád, Being a Translation of the Táríkh Farahbakhsh of Muhammad FaizBakhsh, trans. William Hoey, vol. 1, Allahabad: Government Press, 1888; Muhammad Faiz Bakhsh, Memoirs of Delhi and Faizábád, Being a Translation of the Tárikh Farahbakhsh of Muhammad Faiz-Bakhsh, trans. William Hoey, vol. 2, Allahabad: Government Press, 1889. Both the Nawab and the Company acknowledged the family of Awadh's most powerful khwajasarai, Almas Ali Khan, in the late eighteenth century. J. Bristow, Resident at Lucknow, to Governor-General and Council, India, 13 February 1783, National Archives of India (NAI), New Delhi, FD/SP 27/12/1783 no. 21; J. Bristow, Resident at Lucknow, to J. Cumming, 18 February 1783, NAI, New Delhi, FD/SP 20/01/1784 no. 3; Hibbert, Commander in Chief, to Governor-General and Council, India, 
sometimes equal or senior kin of non-slaves. ${ }^{28}$ Constructed kinship could be affective, as well as power differentiated, and was a conduit for khwajasarais' considerable political influence. In the mid-nineteenth century, khwajasarai kinship and social networks were derided by the British as an avenue for political "corruption," and the British Resident pressured the Awadh ruler, or Padshah, to ban the employment of eunuchs in administrative positions. ${ }^{29}$ The Padshah signed an agreement banning khwajasarais from "official" posts, but not from "private" attendance on the Padshah. ${ }^{30}$ This fundamentally misunderstood where khwajasarais' power lay: in the "inner" domain of the court, due to their physical proximity to the ruler. The Padshah creatively used the European public/private distinction to retain his khwajasarais in important positions of power defined as "private." Meanwhile, khwajasarais continued to exert political power through their networks of kin and dependants. ${ }^{31}$ Ultimately, it took the British annexation of Awadh in 1856 to dislodge the power of the khwajasarais.

The nineteenth-century privileging of the conjugal family unit is part of the story of why khwajasarais were labelled politically "corrupt," and why hijra households and kothas were derided as "deviant" domesticities. In the late eighteenth and early nineteenth centuries, colonial law normalised certain elite Indian codes of domesticity, drawn from textual sources of Hindu and Muslim law, in the process marginalising diverse domestic arrangements, including

16 February 1785, NAI, New Delhi, FD/SC 19/02/1785 no. 1; J. Ironside to Commander in Chief, 25 January 1785, NAI, New Delhi, FD/SC 19/02/1785 no. 2; G. Ironside to Commander in Chief, 26 January 1785, NAI, New Delhi, FD/SC 19/02/1785 no. 4; Almas Ali Khan to Governor-General, India, 19 April 1785, NAI, New Delhi, FD/SC 26/04/1785 no. 24; Edward Otto Ives, Resident at Lucknow, to Governor-General, India, 11 January 1789, NAI, New Delhi, FD/SPC 19/01/1789 no. 13; Edward Otto Ives, Resident at Lucknow, to Governor-General, India, 29 March 1789, NAI, New Delhi, FD/SPC 08/04/1789 no. 22.

28 For examples in Faiz Bakhsh's memoirs, see Faiz Bakhsh, Memoirs, vol. 2, pp. 215-19, 289 and $297-98$.

29 A.F. Richmond, Resident at Lucknow, to Secretary, Government of India, 22 June 1848, NAI, New Delhi, FD/PC 08/07/1848 no. 64; A.F. Richmond, Resident at Lucknow, to Secretary, Government of India, 17 June 1848, NAI, New Delhi, FD/PC 15/07/1848 no. 51-4.

30 Wajid Ali Shah, Padshah of Awadh, "Written Agreement ... as an assurance of His Majesty's intention to prevent Eunuchs, Singers and other improper persons from holding Office under the Oude Government either directly or indirectly in the names of other parties," 22 June 1848, NAI, New Delhi, FD/PC 08/07/1848 no. 65. 31 On Mughal conceptions of political power and proximity to the ruler, see Ruby Lal, Domesticity and Power in the Early Mughal World, Delhi: Cambridge University Press, 2005, pp. 142, 152; Rosalind O'Hanlon, "Kingdom, household and body: history, gender and imperial service under Akbar," Modern Asian Studies, 41(5) (2007): 889-923, pp. 893-94. For examples of the Padshah's correspondence on khwajasarais see: Wajid Ali Shah, Padshah of Awadh, to Resident at Lucknow, 25 June 1847, NAI, New Delhi, FD/PP 11/12/1847 no. 162; Wajid Ali Shah, Padshah of Awadh, to Resident at Lucknow, 30 May 1848, NAI, New Delhi, FD/PC 15/07/1848 no. 51-4; Wajid Ali Shah, Padshah of Awadh, to Resident at Lucknow, 21 June 1855, NAI, New Delhi, FD/PC 28/12/1855 no. 335. On khwajasarais' continued employment in positions of authority see J. Outram, Resident at Lucknow, to Secretary, Government of India, 21 June 1855, NAI, New Delhi, FD/PC 28/12/1855 no. 335. On networks of dependents and household establishments as means by which khwajasarai exercised power, see Richmond to Sec, GoI, 17 Jun 1848, NAI, New Delhi, FD/PC 15/07/1848 no. $51-4$. 
customary forms of marriage and divorce and matrilineal social structures. ${ }^{32}$ Following 1857, colonial interventions into the domestic sphere occurred in marginal communities labelled "criminal," the "deviant fringe" of Indian society. ${ }^{33}$ In the early 1870s, the domestic spaces of regional and caste groups deemed "infanticidal communities," ${ }^{44}$ as well as the "criminal tribes" (caste communities the British regarded as hereditary criminals), were targeted through colonial legislation. Attempts to micro-manage hijra households and kothas through the removal of children are part of this broader history of the marginalisation of diverse South Asian domestic arrangements in the nineteenth century. The colonial concern with the domestic formations of hijras and prostitutes highlights the centrality of the "intimate" to projects of colonial modernity. ${ }^{35}$

In the late nineteenth century, the colonial government was also concerned with the reform of poor and "criminal" children. In the 1860s, the colonial government made its first forays into the upbringing of subaltern Indian children. Previously, the only government-administered orphanages were for the offspring of European men, while the only orphanages for Indian children were run by missionaries and private organisations. ${ }^{36}$ Yet, following the 1860-61 Upper Doab famine, the colonial government established its first orphanages for Indians. ${ }^{37}$ In 1876, concerns with the reform of "criminal" Indian children resulted in the passage of the Reformatory Schools Act. ${ }^{38}$ These projects of reform and education were limited to subaltern children, since "respectable" Indian children were inaccessible to the colonisers. ${ }^{39}$ However, the removal of children was generally considered an illegitimate policy and was rejected in the nineteenth century in other contexts, for instance, the regulation of "criminal tribes." It was not

\footnotetext{
32 Radhika Singha, A Despotism of Law: Crime and Justice in Early Colonial India, Delhi: Oxford University Press, 1998, p. 122; Tambe, Codes of Misconduct, p. 5; Mytheli Sreenivas, "Conjugality and capital: gender, families, and property under colonial law in India," The Journal of Asian Studies 63(4) (November 2004): 937-60, pp. 938-42.

33 Direct colonial intervention in "native" domestic contexts was generally considered illegitimate after the revolt against British rule in 1857. T.R. Metcalf, The Aftermath of the Revolt: India, 1857-1870, Princeton: Princeton University Press, 1964; Guha, "The family feud," p. 91. However, at the margins of Indian society, colonial regulation actually increased. "Deviant fringe" is Radhika Singha's term. Radhika Singha, "Colonial law and infrastructural power: reconstructing community, locating the female subject," Studies in History 19(1) (2003): 87-126. See also, Oldenburg, The Making of Colonial Lucknow.

34 Satadru Sen, "The savage family: colonialism and female infanticide in nineteenth-century India," Journal of Women's History 14(3) (Autumn 2002): 753-73, pp. 53-55.

35 Kathleen Wilson, "Rethinking the colonial state: family, gender, and governmentality in eighteenthcentury British frontiers," American Historical Review 116(5) (December 2011): 1294-322; Ann Laura Stoler, Carnal Knowledge and Imperial Power: Race and the Intimate in Colonial Rule, Berkeley: University of California Press, 2002, p. 8; Durba Ghosh, Sex and the Family in Colonial India: The Making of Empire, Cambridge: Cambridge University Press, 2006, p. 2.

36 David Arnold, "European orphans and vagrants in India in the nineteenth century," Journal of Imperial and Commonwealth History 7(2) (1979): 104-27; Ghosh, Sex and the Family, pp. 206-45.

37 Sen, “The orphaned colony," pp. 465-68.

38 Sen, Colonial Childhoods, pp. 34-39.

39 Sen, "The orphaned colony," p. 474.
} 
until the 1910s that the government removed children from criminal tribe communities. ${ }^{40}$ In this respect, the proposed removal of children from hijra households and brothels went beyond the usually acceptable boundaries of colonial governance, although such proposals occurred in the context of broader colonial interventions into the lives of subaltern Indian children.

Concerns about "deviant" domestic arrangements and children also intersected with anxieties about kidnapping. Throughout the nineteenth century, periodic moral panics over kidnapping occurred in official circles and brought together a range of colonial concerns. ${ }^{41}$ From the early nineteenth century, there was an association between kidnapping, uncontrolled mobility and criminality, ${ }^{42}$ all of which threatened British notions of political authority. ${ }^{43}$ Both prostitutes and hijras were linked to "wandering tribes" who kidnapped children, ${ }^{44}$ while hijras, who led semi-peripatetic lifestyles, were sometimes viewed as kidnappers themselves. ${ }^{45}$ Thus, concerns with prostitute and hijra domesticities resonated with the inability to know and control mobile populations. The colonial government was particularly concerned with kidnapping for "immoral purposes," or prostitution. In contrast, according to the colonisers, the kidnapping of girls for forced marriage was a "venial crime" that was in the interests of the girl, while there was no "shame" in kidnapping for "domestic slavery." ${ }^{46}$ The agency and welfare of the kidnapped child was irrelevant, so

40 Sen, Colonial Childhoods, p. 57.

41 B. Harding, Acting Magistrate of Agra, "Report on Child Stealing in Agra District," 9 December 1830, NAI, New Delhi, FD/PC 21/01/1831 no. 65.

42 Nitin Sinha, "Mobility, control and criminality in early colonial India, 1760s-1850s," Indian Economic and Social History Review 45(1) (2008): 1-33. Wandering tribes, thags (or thugs), gypsies and the criminal tribes were associated with kidnapping. William H. Sleeman, A Report on the System of Megpunnaism, or: The Murder of Indigent Parents for their Young Children (who are Sold as Slaves) as it Prevails in the Delhie Territories, and the Native States of Rajpootana, Ulwar and Bhurtpore, Srirampur: Serampore Press, 1839; C. Hervey, General Superintendent of Operations for the Suppression of Thugee and Dacoity, "Extract, paras X and XXXIV, from a General report of the Operations of the Thugee and Dacoity Department for the year 1862...," 15 September 1863, NAI, New Delhi, FD/JB 11/1863 no. 9-15; H.D. Daly, Officiating Agent, Central India, to Secretary, Government of India, 31 March 1869, NAI, New Delhi, FD/PB 04/1869 no. 224-31; E.C. Bayley, Home Department Memorandum, 2 July 1870, NAI, New Delhi, HD/PB 19/08/1870 no. 12-9; C. Hervey, General Superintendent of Operations for the Suppression of Thugee and Dacoity, to Judicial Commissioner, Central Provinces, 9 March 1863, NAI, New Delhi, FD/JB 11/1863 no. 9-15.

43 Sandria B. Freitag, "Crime in the social order of colonial north India," Modern Asian Studies 25(2) (1991): 227-61; Sanjay Nigam, "Disciplining and policing the 'criminals by birth', part 2: the development of a disciplinary system, 1871-1900," Indian Economic and Social History Review 27(3) (1990): 257-87, pp. 260-66, 272-74. On concerns with uncontrolled mobility and colonial policies towards slavery, see Andrea Major, "Enslaving spaces: domestic slavery and the spatial, ideological and practical limits of colonial control in the nineteenth-century Rajput and Maratha States," Indian Economic and Social History Review 46(3) (2009): 323-29.

44 Inspector-General of Police, Central Provinces, to Secretary, Central Provinces, 24 January 1871, NAI, New Delhi, HD/Police 01/04/1871 no. 14.

45 R. Drummond, Officiating Commissioner of Allahabad, to Secretary, NWP, 9 August 1865, BL, London, IOR, P/438/61; H.D. Willock, Magistrate of Bulandshahr, to Commissioner of Meerut, 9 January 1873, UPSA, Allahabad, COM/29/8.

46 C.A. Elliot, Secretary to Government, NWP, to Secretary, Government of India, 5 September 1870, BL, London, IOR, P/92; Bayley, Memo, 2 Jul 1870, NAI, New Delhi, HD/PB 19/08/1871 no. 12-9; C.A. Elliot, 
long as they ended up in a "respectable" domestic context. Thus, kidnapping intersected with moral outrage at the premature sexualisation of children outside the context of conjugal domesticity, as well as moral rhetoric surrounding the abuse of children and "lost" childhoods.

In some cases, colonial government interventions into childhoods and domestic spaces were informed by evangelism. There were both areas of overlap and considerable tensions between government and missionary agendas towards Indian children. The relationship between the colonial government and missionaries was ambiguous and even conflicted. ${ }^{47}$ However, the provincial government of the North-Western Provinces that initiated the proposed "rescue" of children from hijras and prostitutes, was particularly influenced by evangelism. The Lieutenant-Governor of the NWP in the late 1860s and early 1870s, William Muir, was the "leading lay supporter of missions" in Agra and a lay preacher. ${ }^{48}$ The relationship of evangelical administrators to colonial power was highly problematic, since official policy mandated "neutrality" on religious matters. ${ }^{49}$ Muir negotiated these tensions by espousing neutrality in official matters, although he supported a policy agenda of "moral improvement" with an "evangelical subtext," while unofficially, though openly, expressing evangelical beliefs and supporting missionary work..$^{50}$ Muir was also a controversial critic of Islam, who attacked the apparent absence of an "idea of conjugal unity" in Islam, which he saw as typified by polygamy, divorce and concubinage. ${ }^{51}$ In reference to the NWP, Avril Powell argues that "close identification with missionary interests was a particular mark of this province." ${ }^{152}$ This partly explains the greater resonance of child rescue discourses in the NWP, compared with other provinces. Although government and missionary projects targeting Indian children overlapped in key respects, even in the NWP, many British administrators at the district level were not persuaded by evangelical ideology of the moral imperative to "save" Indian children. The colonial child rescue project was therefore fractured and ambiguous.

Officiating Secretary, NWP, to Officiating Secretary, Government of India, 18 July 1870, NAI, New Delhi, HD/ PB 19/08/1871 no. 12-9; Joint Magistrate of Etah to Commissioner of Agra, 14 January 1870, BL, London, IOR, P/92; G. Hutchinson, Inspector-General of Police, Punjab, to Officiating Secretary, Punjab, 5 August 1872, BL, London, IOR, P/706.

47 See Jeffrey Cox, Imperial Fault Lines: Christianity and Colonial Power in India, 1818-1940, Stanford: Stanford University Press, 2002.

48 Avril A. Powell, Scottish Orientalists and India: The Muir Brothers, Religion, Education and Empire, Woodbridge: Boydell, 2010, p. 92.

49 Ibid., pp. 14-15.

50 Ibid., pp. 91-92.

51 Ibid., pp. 162-67. For the Muslim reaction to Muir's comments, see also Avril A. Powell, “Indian Muslim modernists and the issue of slavery in Islam," in Slavery \& South Asian History, ed. Indrani Chatterjee and Richard M. Eaton, Bloomington, Indiana: Indiana University Press, 2006, pp. 262-86.

52 Powell, Scottish Orientalists and India, p. 93. 


\section{To "rescue" boys from a "life of infamy": Colonial interventions into the hijra household}

In the late nineteenth century, the space of the hijra household, and particularly the presence of children therein, was the subject of considerable moral panic in official colonial circles. From the 1850s and 1860s, colonial discourse, particularly at higher levels of government, represented the hijra household as an environment in which boys were sexually corrupted and taught genderdeviant behaviours. British colonial administrators claimed that coercive and criminal means were used to replicate the hijra community: since hijras were incapable of procreative sexual intercourse, children in hijra households "in many cases, can be proved to have been, and in every case may be presumed to have been, kidnapped." ${ }^{53}$ Hijra households were characterised as an environment of sexual corruption and deviant socialisation. Since hijras were apparently "neither more nor less than professional sodomites," 54 the hijra household was transformed into a mere brothel. ${ }^{55}$ According to British administrators, children, often described as "pupils," were "trained" to become "professional sodomites" in hijra households. ${ }^{56}$ This sexual education was never described in detail, leaving its precise content to the imagination. The hijra household was also a dark and unknowable space for colonial officials. ${ }^{57}$ British colonisers were concerned by lacunae in their knowledge of the hijra household, prompting efforts to discipline and render transparent hijra domestic space through police surveillance and registration. The opacity of the hijra household and the inability to fix and know its various, complex domestic relationships, fuelled moral panic and imparted associations of criminality onto the hijra community.

Yet the records of the lower levels of the colonial administration-including the reports of Indian police officers and intelligence collected from hijras and their neighbours - show a complex, if fragmented, picture of hijra domestic

53 C. Daniell, Magistrate of Farrukhabad, to Commissioner of Agra, 13 January 1870, BL, London, IOR, P/92. See also, S.N. Martin, Magistrate of Muzaffarnagar, to Commissioner of Meerut, 15 July 1865, UPSA, Allahabad, COM/9/2.

54 R. Drummond, Sessions Judge of Shahjahanpur, "General remarks to cases No. 79 of 1864, and Nos. 16, 17, 18 and 19 of 1865," ca. 1865, BL, London, IOR, P/438/61.

55 R. Simson, Secretary, NWP, to Inspector-General of Police, NWP, 9 June 1865, BL, London, IOR, $\mathrm{P} / 438 / 61$; C.A. Elliot, Officiating Secretary, NWP, to Secretary, Government of India, "Abstract of Replies," 21 April 1871, BL, London, IOR, P/92; C.A. Dodd, Officiating Personal Assistant to Inspector-General of Police, NWP, to all Superintendents of Police, NWP, circular no. 11, 30 June 1865, BL, London, IOR, P/438/61; A.O. Hume, Magistrate of Etawah, quoted in J. Simson, Register to Nizamut Adalwut, NWP, “Replies to the Court's Circular letter, No. 4, dated the 2nd September 1865," 20 April 1866, BL, London, IOR, P/438/62.

56 E. Tyrwhitt, Inspector-General of Police, NWP, to Secretary, NWP, 26 June 1874, BL, London, IOR, P/96. 57 O.L. Smith, Deputy Inspector-General of Police, NWP\&O, to Personal Assistant to Inspector-General of Police, NWP\&O, 6 July 1881, BL, London, IOR, P/1614; H.B. Webster, Inspector-General of Police, NWP\&O, to Secretary, NWP\&O, 15 July 1884, BL, London, IOR, P/2208. 
arrangements. ${ }^{58}$ There were multiple axes along which power was organised in hijra households, including age, gender, occupation and positions of authority. Northern India was divided up by hijras so that each hijra household had a territory in which they would request alms and perform in the streets and bazaars and at households where births had recently occurred. ${ }^{59}$ The permanent residents of a household usually numbered between three and eight. ${ }^{60}$ Nineteenth-century hijra households were structured by two primary relationships amongst hijras. First, hijra households were ordered by hierarchical relationships between gurus (teachers) and chelas (disciples). Archived hijra life stories evidence that gurus had significant authority over their chelas ${ }^{61}$ and that gurus and chelas lived and migrated together. ${ }^{62}$ Yet gurus also imparted to chelas the art of singing and dancing; hijras' bawdy jokes, insults and parodies; hijra ritual practices and mythologies; and in some cases, medical expertise in the emasculation operation. ${ }^{63}$ Second, hijra households also featured more affective, though nevertheless status-differentiated, relationships between hijras, which

58 Like Stoler, I have found the "surplus production [of official state archives], what defines their interior ridges and porous seams," are sites where "out of place" opinions surface. Ann Laura Stoler, Along the Archival Grain: Epistemic Anxieties and Colonial Common Sense, Princeton: Princeton University Press, 2009, pp. 2, 14. In particular, my research into hijras suggests that colonial knowledge was formed in interaction with the knowledge of Indian informants. This produced tensions in official knowledge at the district level, where colonial officials came into contact with local, vernacular knowledge. I have drawn on Rosalind O'Hanlon's and Christopher Bayley's work. Rosalind O'Hanlon, "Recovering the subject: subaltern studies and histories of resistance in colonial South Asia," Modern Asian Studies 22(1) (1988): 189-224, pp. 215-17; C.A. Bayly, Empire \& Information: Intelligence Gathering and Social Communication in India, 1780-1870, New Delhi: Cambridge University Press, 1999, pp. 143, 161-78.

59 W. Oldham, Officiating Magistrate of Ghazipur, to Commissioner of Benares, 6 February 1875, UPSA, Allahabad, COV/119/12; Simson, "Replies," 20 Apr 1866, BL, London, IOR, P/438/62; B. Sapte, Officiating Commissioner of Agra, to Secretary, NWP, 16 September 1865, BL, London, IOR, P/438/61.

60 H.B. Webster, Magistrate of Meerut, "Register of Eunuchs in the Meerut District coming under Section 24 Act XXVII of 1871," 7 May 1873, UPSA, Allahabad, COM/29/8; Magistrate of Bulandshahr (signature illegible), "Register of property possessed by Eunuchs borne on the rolls of Register No. 1 zillah Bollundshuhur," 9 January 1873, UPSA, Allahabad, COM/29/8; Officiating Superintendent of Police, Meerut (signature illegible), "Register of the Eunuchs in the District of Meerut Coming Under Section 24 of Act 27 of 1871," 23 April 1872, UPSA, Allahabad, COM/29/8; H.B. Webster, Magistrate of Gorakhpur, "Register of property possessed by Eunuchs borne on the Rolls of Register No. 1 under Act XXVII of 1871 District Goruckpore," ca. 1872-73, UPSA, Allahabad, COV/119/12; Rose, A Glossary of the Tribes and Castes, p. 332.

61 These life stories were relayed by hijras themselves and by their neighbours and were reported and selected by Indian subordinate police. W.A. Short, Superintendent of Police, Muzaffarnagar, "List of Eunuchs in the District of Mozuffurnuggur," ca. January 1873, UPSA, Allahabad, COM/29/8. We also know that chelas were expected to cook and clean for their guru. North-Western Provinces Nizamut Adawlut, "Government v. Ali Buksh," Decisions of the North-Western Provinces Nizamut Adawlut 2 (1852): 1314-16.

62 James Amson, Magistrate of Azamgarh, to Commissioner of Benares, 16 November 1872, UPSA, Allahabad, COV/119/12.

63 On the training of hijras by their gurus, see: R.E. Enthoven, The Tribes and Castes of Bombay, vol. 3, New Delhi: D.K. Publishers Distributors, 1997 [1922], p. 227; Bhimbhai Kirparam, "Pavávás," in Hindu Castes and Tribes of Gujarat, vol. 2, ed. James M. Campbell, Haryana (India): Vintage Books, 1988 [1901], pp. 506-08; Rose, A Glossary of the Tribes and Castes, p. 332. On the emasculation operation, see Amson to Comm Benares, 16 Nov 1872, UPSA, Allahabad, COV/119/12. In a given area, there was usually one guru who had authority over other hijra gurus and chelas. Short, "List," ca. 1873, UPSA, Allahabad, COM/29/8. 
were described through kinship terms. H.A. Rose, a colonial ethnologist, reported that hijras in the Punjab "call one another by such names as mási, 'mother's sister,' phuphi, 'aunt,' and so on." ${ }^{64}$

The colonial archive suggests, despite colonial rhetoric, that the formation and reproduction of hijra households cannot be reduced to kidnapping. Nineteenthcentury hijras joined the community as both adults and children, ${ }^{65}$ while children joined hijra households in several circumstances: some children were kidnapped and then sold to hijras, ${ }^{66}$ particularly in periods of political and social unrest, such as $1857-58 ;{ }^{67}$ relatives sometimes sold or gave away children due to financial distress, the death of a parent or a genital "deformity" in the child; ${ }^{68}$ while in periods of famine, hijras adopted or took in children. ${ }^{69}$ In the early nineteenth century, the average age of emasculation had been eleven or twelve, although a significant minority of hijras were emasculated in their late teens or adulthood. ${ }^{70}$ However, by the mid- to late nineteenth century, the numbers of children in hijra communities were small (around 61 in 1871) and very few were emasculated - in 1871, police found only one child eunuch. ${ }^{71}$ In sum, there were multiple paths into the hijra community, for both adult and child initiands.

Hijra households were also home to non-hijras. Hijras sometimes adopted children whom they intended to marry to a suitable partner, rather than initiate as hijras, and were thus invested in the formation of conjugal and reproductive domesticities through adoption. ${ }^{72}$ Some of the children in hijra households were

64 Rose, A Glossary of the Tribes and Castes, p. 332.

65 The colonial records mention several examples of the initiation of hijra as adults. Drummond, "General Remarks," ca. 1865, BL, London, IOR, P/438/61; R.F. Saunders, Magistrate of Ghazipur, to Commissioner of Benares, 30 October 1872, UPSA, Allahabad, COV/119/12; J. Woodburn, Secretary, NWP\&O, to InspectorGeneral of Police, NWP\&O, 1 July 1885, BL, London, IOR, P/2460; E. Berril, Deputy Inspector-General of Police, NWP\&O, to Inspector-General of Police, NWP\&O, 1 May 1896, UPSA, Allahabad, COA/18/5. However, officials emphasised instances of child castration over adult castration. Sapte to Sec, NWP, 16 Sep 1865, BL, London, IOR, P/438/61; E.C. Bayley, Secretary to Government, Bengal, to Secretary to Government of India, 8 May 1865, NAI, New Delhi, HD/JB 30/07/1870 no. 53-54; Simson, "Replies," 20 Apr 1866, BL, London, IOR, P/438/62.

66 North-Western Provinces Nizamut Adawlut, "Government v. Munsa and 4 others," Decisions of the North-Western Provinces Nizamut Adawlut 10 (1860): 6 March 1860; Drummond, "General Remarks," ca. 1865; Sapte to Sec, NWP, 16 Sep 1865, BL, London, IOR, P/438/61.

67 Dalmahoy, “Report," 9 Dec 1865, BL, London, IOR, P/438/61.

68 Ibid.; Sapte to Sec, NWP, 16 Sep 1865, BL, London, IOR, P/438/61.

69 F. Williams, Commissioner of Meerut, to Secretary, NWP, 31 January 1870, BL, London, IOR, P/92; Magistrate of Muttra to Commissioner of Agra, 26 January 1871, BL, London, IOR, P/92.

70 Webster, "Register," 7 May 1873, UPSA, Allahabad, COM/29/8; Campbell, “Register," 6 Jan 1872, UPSA, Allahabad, COM/29/8; B. Alone, Officiating Superintendent of Police, Azamgarh, "Register of Eunuchs in the District of Azimgurh," 9 October 1872, UPSA, Allahabad, COV/119/12.

71 Dennehy to IG Police, 15 Aug 1871, BL, London, IOR, P/92. Considering that the NWP government believed there were "at least 2,500" eunuchs in the NWP, this represents a relatively small number. Court quoted in Simson, "Replies," 20 Apr 1866, BL, London, IOR, P/438/62.

72 For instance, a hijra named Goolbuddun in Azamgarh district "brought up a boy" who became a "married man, and the father of a family." Amson to Comm Benares, 16 Nov 1872, UPSA, Allahabad, COV/119/12. 
the offspring of widows who took shelter with hijras ${ }^{73}$ The families of musicians who performed with hijras also sometimes lived with hijras, accounting for around one in five children in hijra households. ${ }^{74}$ Some hijras also had longterm relationships with normatively masculine men who lived permanently or for periods with their hijra partner. ${ }^{75}$ The complexities of hijra domesticities can be further seen in their mythology. On the one hand, hijra legends positioned hijras as impotent and infertile men who should be emasculated and dress as women, and thus place themselves outside procreative masculinities. ${ }^{76}$ On the other hand, hijras' association with infertility endowed them with power to bless and curse fertility and the right to collect alms and perform songs and dances following births, thus explicitly linking hijra existence to procreative sexualities. In sum, hijra households were complex and featured both nonbiological and biological kinship, as well as various relationships of dependence. Hijras were separate to and yet linked to conjugal, procreative domesticities through their social role, mythology and adoptive practices.

Yet ethnological detail of hijra domesticities in colonial records was generally subsumed in a narrative that characterised hijra households as an environment that "corrupted" and victimised children. Much of the discursive power of moral panic concerning hijras was derived from the rhetoric of lost childhood and the figure of the kidnapped and abused child. For the legislator J.F. Stephen, "the depositions of the children who had been kidnapped and mutilated ... [were] as frightful stories as were ever told in the world." ${ }^{77}$ Colonial officials sometimes voiced their moral duty in explicitly Christian terms, characterising hijras as a "reproach to any country under Christian rulers."78 Thus, the government removal of children from hijra households was an experimental foray into the missionary agenda of rescuing "lost" children.

However, colonial officials also conceptualised the bodies of boys as crucial to the control of the hijra community. The articulated aim of government was the extermination of eunuchs, effected by the prevention of emasculation, and this

73 Short, "List," ca. 1873, UPSA, Allahabad, COM/29/8; R.T. Hobart, Deputy Inspector-General of Police, NWP, to Inspector-General of Police, NWP, 28 June 1876, BL, London, IOR, P/839; Office of the Commissioner of Benares (signature illegible), "Abstract of replies of Magistrates of Districts of the Benares Division to Commissioner's Circular No: 39," 23 November 1875, UPSA, Allahabad, COV/119/12.

74 J.J.F. Lumsden, Officiating Magistrate of Gorakhpur, to Commissioner of Benares, 15 April 1873, UPSA, Allahabad, COV/119/12.

75 NWP Nizamut Adawlut, "Govt v. Ali Buksh," pp. 1314-16.

76 The purpose of emasculation was to prevent rebirth as impotent in future lives. Thus, hijra mythology positioned fertility as a good, highlighting the paradoxical negation of conjugal and procreative sexualities and their reinforcement. Enthoven, The Tribes and Castes, p. 227; John Shortt, "The Kojahs of southern India," The Journal of the Anthropological Institute of Great Britain and Ireland 2 (1873): 402-07, p. 403.

77 J.F. Stephen, Member of the Council of the Governor-General of India, quoted in W. Stokes, Secretary, Government of India, Abstract of the proceedings of the Council of the Governor-General of India, 2 December 1870, BL, London, IOR, V/9/11.

78 G. Couper, Secretary, NWP, to Member of the Legislative Council of India for the NWP, 12 February 1861, BL, London, IOR, P/235/33. 
goal depended on the control of male child bodies. Colonial officials argued that it would not be possible "to eradicate this unnatural race, ${ }^{\prime 79}$ if more eunuchs could be created out of the bodies of unemasculated boys.$^{80}$ While in the Indian conception, hijras were endowed with power over the fertility of others and were therefore ambiguously linked to procreative sexualities, British colonial officials viewed hijras as entirely opposed to procreation. Hijra domestic arrangements, guru-chela hierarchies and kinship-making practices were viewed as perverse sites of the reproduction of hijra bodies.

According to the NWP government, the removal of children who resided with hijras would achieve the dual aims of: first, "rescuing" boys from the hijra household and reversing their deviant socialisation through reform; and second, preventing their emasculation and thereby causing the hijra community to die out. Children were first removed from hijra households in the NWP by executive order in 1865, although at this stage there was no legal basis for removal. The NWP argued legislation was necessary and pushed for the passage of Part II of the Criminal Tribes Act of 1871, which provided for the registration of eunuchs. However, the NWP was the only government that registered eunuchs or removed children from hijra households, demonstrating the limited nature of this experiment in child rescue.

\section{"Prostitute" domesticities and a failed project of child "rescue"}

The removal of children from hijra households opened up the question of whether children should be removed from another domestic space considered "deviant," the kotha or brothel. As we have seen, prostitution was a term that encompassed a diverse range of economic, social and cultural practices. Below, I will examine two figures labelled prostitutes - the brothel worker and the courtesan - who were of concern in north and central India. ${ }^{81}$ There is a considerable body of

\footnotetext{
79 S.N. Martin, Magistrate of Muzaffarnagar, to Commissioner of Meerut, 15 July 1865, UPSA, Allahabad, $\mathrm{COM} / 9 / 2$.

80 For example, W.G. Probyn, Magistrate of Shahjahanpur, to Sessions Judge of Shahjahanpur, 12 December 1864, BL, London, IOR, P/438/61; Simson to IG Police, NWP, 9 Jun 1865, BL, London, IOR, P/438/61; Officiating Judge of Azamgarh, quoted in Elliot, "Abstract," 21 Apr 1871, BL, London, IOR, P/92; C. Robertson, Commissioner of Allahabad, to Secretary, NWP, 27 June 1866, BL, London, IOR, P/438/62; C. Robertson, Officiating Secretary, NWP\&O, to Inspector-General of Police, NWP\&O, 3 April 1877, BL, London, IOR, P/840; Tiernan, 2nd Grade Inspector of Police, Gorakhpur, to Superintendent of Police, Gorakhpur, 26 May 1871, BL, London, IOR, P/92; C.R. Lindsay, Sessions Judge of Moradabad, quoted in Simson, "Replies," 20 Apr 1866, BL, London, IOR, P/438/62.

81 Devadasisare evident largely in South India. The removal of girls from devadasi communities was considered by Madras Presidency, but was not considered advisable or desirable. Due to the constraints of
} 
literature on prostitution in colonial India, ${ }^{82}$ although few studies have analysed brothels, or kothas, as domestic contexts. Two studies stand out in this respect, but diverge in their approach. Veena Oldenburg argued in her study of the courtesans, or tawa'if, of Lucknow that the kotha was an alternative to conjugal respectable domesticity and courtesans' "lifestyle" constituted "resistance" to patriarchy. ${ }^{83}$ Ashwini Tambe has recently challenged Oldenburg's argument, demonstrating that "commercial sex was an entirely domestic activity, performed in continuity with [women's] personal identities within the 'family." 84 Tambe notes the presence of multiple familial relationships in Bombay kothas ranging from procuring from within the biological or conjugal family to calling brothel mistresses "mother" and fellow brothel workers "sister." Brothels could function as an alternate family for women who escaped hegemonic family life, but were not an alternative to familial domesticity. ${ }^{85}$ Kinship could also play a "mystifying function, hiding coercive relations." ${ }^{86}$ Although Tambe's argument that brothels were experienced as families is convincing, she positions actual and fictive kinship as a duality, ${ }^{87}$ adopting the approach of many anthropological studies that conceptualise non-biological kinship as fictive kinship. Based on my research into hijras and khwajasarais, I would posit constructed kinship as a more appropriate concept for kinship-making practices that encompassed formal adoption, de facto kinship and the symbolic or discursive deployment of kinship.

Whereas Tambe's study focuses on the early twentieth century, archival material from the nineteenth century suggests similar contours of relationships within kothas. Biological kinship was an entry point into prostitution, while mothers, daughters and other female relatives sometimes lived together in kothas. For instance, we learn of a widow and her daughter who together entered a brothel in Agra in the 1860s and of Mussamut Gujra, a powerful courtesan in the Indian-ruled principality of Bharatpur who had trained her daughter, Mussamut Beejan, as a courtesan. ${ }^{88}$ Adoption within kothas was also common

this paper, my greater familiarity with North India, and the origination of the proposal in the NWP, I focus on the social roles classified as "prostitution" that were the concern there. I also examine Rajasthan and central India, because this region was thought to be a major market for underage prostitutes in the north.

82 See for example Ballhatchet, Race, Sex and Class; Levine, Prostitution, Race and Politics; Tambe, Codes of Misconduct; Oldenburg, "Lifestyle as resistance"; Whitehead, "'Bodies clean and unclean.'”

83 Oldenburg, "Lifestyle as Resistance," pp. 259-87.

84 Aswini Tambe, "Brothels as families: reflections on the history of Bombay's Kothas," International Feminist Journal of Politics 8(2) (2006): 219-42, p. 228.

85 Ibid., p. 233.

86 Ibid., p. 228.

87 Tambe does write that the "line between actual and fictive kinship blurs when one examines brothel relations more closely," but nonetheless equates "actual" kinship with biological kinship, suggesting all other forms were "fictive." Ibid.

88 Gujra's status as either slave-concubine or courtesan is obscure in the records, demonstrating the conflation of multiple social roles under the label "prostitute." C.K.M. Walter, Political Agent, Bharatpur, to Agent, Rajputana, 17 September 1868, NAI, New Delhi, FD/PB 10/1868 no. 218. 
and brothel workers and courtesans often adopted the daughters of women in different kothas. ${ }^{89}$ Young courtesans and brothel workers often called the brothel mistress their "mother." Beejan lived with a young courtesan and "treated her as a daughter," 90 while one girl who was sold to a kotha in Mahi Kantha (Gujarat) subsequently refused to leave the woman she was sold to, whom she called her mother. ${ }^{91}$ One colonial official reported that girls were often unwilling to leave kothas because of biological or adoptive kinship, since "their natural protectors" were "their mothers." ${ }^{\prime 2}$ The deployment of biological and constructed kinship evidently had coercive effects, keeping girls in prostitution by creating ties of loyalty and obligation, ${ }^{93}$ but it could also have affective aspects. Birth into prostitution, being given or sold to kothas by parents and entering prostitution in circumstances of distress (such as widowhood or poverty) were the most common avenues into brothels and courtesan establishments. ${ }^{94}$

Despite this evidence of biological and constructed kinship in kothas, most British administrators claimed criminal means were used to secure new recruits to kothas. One theory was that prostitutes were linked to networks of "wandering" tribes who provided a steady supply of kidnapped girls. ${ }^{95}$ Thus, the complex relationships of both hijra households and kothas were equated with kidnapping and both domestic spaces were viewed as sites of criminality. ${ }^{96}$ Whereas the Government of India concluded in 1871 that the "traffic in young persons, chiefly females" was "habitually practiced," divided on whether this was the case. Many argued that girls were given or sold

89 T.W. Mercer, Deputy Commissioner, Jalandhar, to Commissioner and Superintendent, Jalandhar, 27 May 1872, BL, London, IOR, P/706.

90 Walter to Agent, Rajputana, 17 Sep 1868, NAI, New Delhi, FD/PB 10/1868 218.

91 J. Black, Political Agent, Mahi Kantha, to Secretary, Bombay, 26 September 1865, NAI, New Delhi, FD/ Police 19/08/1871 no. 13(e).

92 Mercer to Comm \& SI, Jalandhar, 27 May 1872, BL, London, IOR, P/706.

93 Tambe, "Brothels as families," p. 228.

94 This conclusion concurs with both Oldenburg's and Tambe's findings. Oldenburg, "Lifestyle as resistance," pp. 264-67; Tambe, "Brothels as families," pp. 230-34.

95 The dominant colonial narrative was of a "respectable" Hindu girl kidnapped and condemned to life as a Muslim prostitute. Walter to Agent, Rajputana, 17 September 1868, NAI, New Delhi, FD/PB 10/1868 no. 218. However, orphans and street children were probably more susceptible to abduction. IG Police, $\mathrm{CP}$, to Secretary, CP, 24 January 1871, NAI, New Delhi, HD/Police 01/04/1871 no. 14.

96 This resonated with a broader marginalisation of certain indigenous forms of adoption in colonial law and policy. For instance, the adoption practices of Indian rulers were rejected by the colonial government as a legitimate succession practice and rulers were forced to appoint successors who were biological kin. Chatterjee, Gender, Slavery and Law, pp. 73-77.

97 George Campbell, Secretary of State for India to Government of India, 9 March 1871, BL, London, IOR, HD/PB 19/08/1871 no. 12-19. 
by their parents or relatives, either because they were "voluntarily immoral persons" " $^{\prime 98}$ with a "want of chastity," ${ }^{\prime 99}$ or because they were driven to do so by destitution and poverty. ${ }^{100}$

Both the kidnapping and sale-by-family theories assumed that girls were not the offspring of prostitutes and several administrators explicitly stated that prostitutes were usually barren women. ${ }^{101}$ The Commissioner of Lucknow reported that "it is well known that native prostitutes hardly ever bear children," 102 while one high-ranking NWP police officer concluded that "there are few children born to prostitutes - the race is not fruitful." ${ }^{103}$ Thus, both hijras and (less obviously) prostitutes were associated with infertility in colonial discourse. The assumption of prostitute barrenness highlights that the British conflated non-conjugal and extra-procreative sexualities with infertility and both were particularly associated with deviant forms of domesticity. Only a few colonial administrators argued that kothas were internally reproduced from prostitute offspring. ${ }^{104}$

The NWP government proposed changes to the Penal Code to make it easier to prosecute brothel-keepers, ${ }^{105}$ as well as legislation for the registration of brothel inmates and the withdrawal of any minor whose "possession" was not satisfactorily explained "for the purposes of sending the minor to a reformatory or other institution appointed by Government." ${ }^{106}$ Draft legislation compiled in nearby Punjab made it clear that the purpose of "rescuing" girls was to place them in respectable, conjugal domestic environments: a removed girl could only

\footnotetext{
98 Officiating Deputy Commissioner of Ajmere and Mairwarra to Commissioner of Ajmere and Mairwarra, 15 February 1870, BL, London, IOR, P/92.

99 E. Tyrwhitt, Deputy Inspector-General of Police, NWP, to Secretary, NWP, 22 February 1870, BL, London, IOR, P/92.

100 C.W. Moore, Officiating Magistrate of Etawah, to Commissioner of Agra, 29 January 1870, BL, London, IOR, P/92; Daly to Sec, GoI, 31 Mar 1869, NAI, New Delhi, FD/PB 04/1869 no. 226; H.D. Daly, Officiating Political Agent, Gwalior, to Agent, Central India, 25 January 1869, NAI, New Delhi, FD/PB 04/1869 no. 227; Hutchinson to Sec, Punjab, 5 Aug 1872, BL, London, IOR, P/706.

101 E.C. Bayley, Home Department Memorandum, 29 November 1871, NAI, New Delhi, HD/JB 04/1872 no. 109-111.

102 J. Reid, Commissioner of Lucknow, Memorandum, 21 June 1872, BL, London, IOR, P/706.

103 Tyrwhitt to Sec, NWP, 22 Feb 1870, BL, London, IOR, P/92.

104 This was the case even though the implementation of the Contagious Diseases Acts from the late 1860s demonstrated that hundreds of registered prostitutes gave birth each year. A. Mackenzie, Officiating Secretary, Bengal, to Officiating Secretary, Government of India, 17 October 1872, BL, London, IOR, P/706. 105 It was argued that changes to the Penal Code were required to make it illegal to "retain" a minor for prostitution, since section 372 and 373 only criminalised buying, hiring or obtaining a minor for prostitution. Tyrwhitt to Sec, NWP, 22 Feb 1870, BL, London, IOR, P/92; F. Henvey, Junior Secretary to Government, NWP, to Secretary, Government of India, 22 April 1870, BL, London, IOR, P/92.

106 E. Tyrwhitt, Officiating Inspector-General of Police, NWP, to Officiating Secretary, NWP, 1 July 1871, $\mathrm{BL}$, London, IOR, P/92.
} 
leave her appointed guardian at sixteen, or when "married with the approval of her guardian" to a husband who "consent[ed] to ... keep her in a place other than a brothel." 107

Yet colonial officials across India were divided on whether the removal of girls was advisable, necessary and morally imperative. Within the central government, two high-ranking officials voiced opposing views. While E.C. Bayley emphasised the moral duty to rescue girls, ${ }^{108}$ H.S. Cunningham, argued that since prostitution was a universal habit and a national practice in India, registering brothels was unthinkable; the Penal Code amendments were too harsh; and the liberty of thousands of girls to whom prostitution was congenial would be violated by their rescue. ${ }^{109}$ Different provincial governments variously argued that Indian opinion was not yet sufficiently enlightened; ${ }^{110}$ suggested that the problem of kidnapping and child prostitution had been exaggerated; ${ }^{111}$ baulked at the practical difficulties involved in taking responsibility for removed children; ${ }^{112}$ or suggested that registration would be futile due to women's resistance. ${ }^{113}$ As such, the Government of India rejected the proposed removal of children from brothels. ${ }^{14}$

However, the discussion of underage prostitution mutated from proposals for a child "rescue" project - with all the assumptions about morality, femininity, respectable conjugal domesticity and criminality that this implied-into a debate about the best means of securing male access to young prostitute bodies. Ultimately, the colonial government prioritised the legal protection of male clients of underage prostitutes over the prevention of underage prostitution. This demonstrates the tenuous hold on British officials of discourses of "lost" childhood and the colonial moral imperative to "save" Indian children. Two recent court cases had raised the question of whether a client could be prosecuted for obtaining a minor for the purposes of prostitution. ${ }^{115}$ There was consensus amongst British administrators that the Penal Code was intended to

107 “Captain Newbery's Bill to Prevent the Prostitution of Female Children," ca. 1872, BL, London, IOR, P/706. See also, Hutchinson to Sec, Punjab, 5 Aug 1872, BL, London, IOR, P/706.

108 Bayley, Memo, 29 Nov 1871, NAI, New Delhi, HD/JB 04/1872 no. 109-111.

109 H.S. Cunningham, Home Department Memorandum, 23 August 1871, NAI, New Delhi, HD/JB 04/1872 no. 109-111.

110 R.S. Ellis, Secretary, Madras, to Officiating Secretary, Government of India, 18 October 1872, BL, London, IOR, P/706; J. Nugent, Acting Under-Secretary, Bombay, to Secretary, Government of India, 19 August 1872, BL, London, IOR, P/706.

111 Mackenzie to Sec, GoI, 17 Oct 1872, BL, London, IOR, P/706; Ellis to Sec, GoI, 18 Oct 1872, BL, London, IOR, $\mathrm{P} / 706$.

112 Hutchinson to Sec, Punjab, 5 Aug 1872, BL, London, IOR, P/706; Mackenzie to Sec, GoI, 17 Oct 1872, BL, London, IOR, P/706; Ellis to Sec, GoI, 18 Oct 1872, BL, London, IOR, P/706;. Barrow, Officiating Deputy Secretary, Oudh, to Secretary, Government of India, 3 July 1872, BL, London, IOR, P/706.

113 Hutchinson to Sec, Punjab, 5 Aug 1872, BL, London, IOR, P/706.

114 C. Lyall, Secretary, Government of India, to Secretary, NWP, 4 July 1873, BL, London, IOR, P/96.

115 H. Wellesley, Officiating Under-Secretary, Government of India, to Secretary, NWP, 17 January 1873, BL, London, IOR, P/96. 
prevent trafficking ${ }^{116}$ and did not extend to "persons who get possession of minors for the gratification of their own lusts and passions." ${ }^{117}$ To clarify this, government considered that an amendment to the Penal Code was necessary. Male access to prostitutes, even underage girls, needed to be secured to "save ... innocent" men who might be unfairly prosecuted. ${ }^{118}$ Several administrators also proposed that the age of girls protected under the Penal Code should be lowered from sixteen to twelve or fourteen because by sixteen a girl was in the "full swing of her trade" — especially since Indian girls apparently reached puberty earlier than European girls - and the prosecution of a brothel keeper in these circumstances would be "quite appalling."119

While the proposal to remove children from hijra households was passed into law under the CTA in 1871, a government-directed program for the removal of children from kothas never eventuated, demonstrating the limits of both colonial government attempts at child "rescue" and the colonial governance of the domestic arrangements of colonised populations. ${ }^{120}$ This was the case for a number of reasons related to: the practicalities and priorities of colonial administration; elite Indian opinion; and differing colonial attitudes towards male and female childhoods. First, the removal of children from the hijra community - which was thought to number 2,500 in the NWP-represented a more confined and practical site for an experiment in child rescue than the removal of girls from kothas, the scope of which would be enormous. ${ }^{121}$ Second, government priorities did not accord with child removal from brothels. Through the Cantonment Act (1864) and Contagious Diseases Act (1868), the colonial government was invested in providing prostitutes for its troops, and more broadly, with racially segregating and controlling, rather than limiting, prostitution. ${ }^{122}$ Third, whereas "respectable" Indians consulted on removal and registration in hijra communities did not oppose these measures, there was significant opposition amongst elite Indians consulted on prostitution. ${ }^{123}$

\footnotetext{
116 Acting Secretary, Madras, to Secretary, Government of India, 22 April 1872, BL, London, IOR, P/706; H.B. Harrington, Officiating Secretary, Oudh, to Secretary, Government of India, 29 April 1872, BL, London, IOR, $\mathrm{P} / 706$.

117 G. Couper, Judicial Commissioner, Oudh, to Secretary, Oudh, 12 October 1865, BL, London, IOR, P/706.

118 J.H. Prinsep, Judge of Kanpur, to Secretary, Oudh, 14 March 1873, BL, London, IOR, P/706.

119 Couper to Sec, Oudh, 12 Oct 1865, BL, London, IOR, P/706. See also, B.W. Colvin, Officiating Sessions Judge of Allahabad, to Secretary, NWP, 19 February 1873, BL, London, IOR, P/96; H.B. Henderson, Judge of Shahjahanpur, to Secretary, NWP, 26 March 1873, BL, London, IOR, P/96.

120 In the 1920s and 1930s, organisations such as the Bombay Vigilance Association and the League of Mercy attempted to remove and reform girls born into brothels but often met with significant opposition from the girls and their mothers. Tambe, "Brothels as families," p. 227.

121 The determination of the parentage of girls in kothas also posed a significant practical problem, whereas boys were clearly not the offspring of eunuchs, who could thus be deemed illegitimate guardians more easily. 122 On the regulation of prostitution see, Ballhatchet, Race, Sex and Class; Levine, Prostitution, Race, and Politics; Tambe, Codes of Misconduct.

123 This was particularly since some groups classed as prostitutes, such as the tawa'if and devadasi, were patronised by powerful men. Moreover, devadasis were still viewed in this period as important to Hindu rituals and customs. Ellis to Sec, GoI, 18 Oct 1872, BL, London, IOR, P/706.
} 
Finally, while the colonisers expressed concern about the premature sexualisation of both boys and girls, they were more willing to do something about the perceived corruption of boys during this period. In the 1860s and 1870s, the establishment of reformatories and the introduction of separate quarters for juveniles in jails were partly motivated by anxieties provoked by sexual relations between boys and adult prisoners. ${ }^{124}$ For the colonial government, the loss of male childhoods to so-called sexual corruption was more concerning than female premature sexuality because "unnatural" sexuality between men and children was at stake in the moral panic over male child sexuality. Moreover, the British thought that Indian girls reached puberty much earlier than Indian boys or European children, and as such, their sexual behaviours in childhood were often regarded as a natural phenomenon. ${ }^{125}$ The failure of the proposal to remove girls from brothels - and the transformation of this proposal into a discussion about how best to protect the male clients of underage prostitutes - highlights the limits of the colonial government's child rescue agenda. The ambiguities of government projects targeting marginalised children also became evident when children were removed from hijra households.

\section{The removal of children from hijra households and the limits of reform}

Although the imperative to "save" children from a "life of infamy" in the hijra community pervaded official discussion of eunuchs, British district administrators debated whether reforming such children and bringing them up according to notions of respectability was in fact possible. Colonial officials at different levels of the provincial government often disagreed on whether the removal and reform of children in hijra households was a worthwhile exercise. The fractures of the colonial child rescue project were further evidenced by the ambiguous role of missionaries in the removal of children from hijra households, demonstrating areas of tension between government and missionary projects targeting children. Despite the stated aim of reforming removed children, in practice the education and upbringing of children was deprioritised, highlighting the limits of the government-directed child rescue project and colonial interventions into indigenous domestic arrangements. Instead, the provincial government concentrated its efforts on the removal and ongoing surveillance of children to ensure their separation from hijras, prevent

124 For official discussion of sodomy, juvenile prisoners and prison reform see correspondence in NAI, New Delhi, HD/JB 19/06/1869 no. 14-5; NAI, New Delhi, HD/JB 24/07/1869 no. 36-7; NAI, New Delhi, HD/ JB 11/10/1865 no. 35-6; NAI, New Delhi, HD/JB 11/05/1870 no. 59-60. See also, Sen, Colonial Childhoods, pp. 69-70.

125 Pande, “Coming of age," pp. 208-09. 
the reproduction of the hijra community and thus cause hijras to die out. The surveillance of children was also considered imperative due to the threat of children's resistance and the possibility they would return to hijras. Official colonial records reinscribe the stories and experiences of removed children in terms of their victimisation, or in the case of the resisting child, of their criminality. Unlike the young "Pearl-eyes" in Annie McCarthy's study (this volume), the agency of children removed from the hijra household was not viewed as "innocent," but rather as subversive, dangerous and corrupting. Yet fragments of the wilfulness and agency of children nevertheless emerge from the colonial archive.

From the mid-1860s, British colonial officials disagreed on whether child rescue was possible and should be attempted, highlighting the fissures within colonial projects targeting the morality of Indian children. Colonial officials believed hijra deviance was partially biologically grounded. While past a certain age, the child would no longer be capable of responding to positive influence and moral improvement, the deviance of children was also apparently hardened by the physical changes of emasculation. ${ }^{126}$ As such, officials argued that some children in hijra households could be transformed into moral and industrious adults.

The question of whether children in hijra households were capable of reform came to the fore in 1865 when NWP officials proposed the establishment of a reformatory asylum. ${ }^{127}$ The Commissioner of Meerut, F. Williams, was optimistic that although removed children were "acquainted" with the "vicious habits" of hijras, "as minors, there are hopes of recovering them from ... degrading prostitution." 128 Children should be taught a "useful trade" (since labour had moral value), separated from hijras and kept under surveillance so they would "get to be ashamed of the lives they were being brought up to." ${ }^{129}$ However, Court, the Inspector-General of Police, considered the emasculated boy hijra a contaminating agent and argued that the separation of emasculated and non-emasculated children in the reformatory was imperative "to prevent [emasculates] from spreading and continuing "contamination."' Whereas both should be "be taught some trade," only "entire males" should be allowed to leave when "full of age" and "eunuchs should never be allowed to leave such

\footnotetext{
126 On the one hand, according to colonial administrators, the plasticity of childhood had limits and past a certain age - sixteen for children in hijra households under law - the child was no longer capable of positive influence and their deviant socialisation would be frozen. Act No. XXVII of 1871, BL, London, IOR, V/8/42. Sen has noticed a similar discourse in relation to boys in the reformatory. Sen, Colonial Childhoods, p. 55. On the other hand, the emasculation of the boy child apparently hardened their deviant character, produced physical effeminacy and a desire for deviant sexual behaviours, and made it inevitable that in adulthood they would become "addicted" to emasculating children. Norman Chevers, A Manual of Medical Jurisprudence for India, Including the Outline of a History of Crime Against the Person in India, Calcutta: Thacker, Spink \&Co., 1870, p. 497; Probyn to Sess Judge, Shahjahanpur, 12 Dec 1864, BL, London, IOR, P/438/61.

127 Court quoted in Simson, “Replies," 20 Apr 1866, BL, London, IOR, P/438/62.

128 F. Williams, Commissioner of Meerut, to Secretary, NWP, 20 November 1865, BL, London, IOR, P/438/62. 129 Ibid.
} 
asylum." ${ }^{130}$ Other officials argued that efforts to reform removed boys would be futile, whether they were emasculated or not, since "they will eventually join the degraded class for which they were intended." ${ }^{131}$ In sum, while some British administrators were optimistic about the capacity of children in hijra communities to reform, many officials did not view saving children as either an achievable goal or a moral duty.

A reformatory for children removed from hijra households never eventuated due to opposition from the central government. ${ }^{132}$ Nonetheless, the NWP government proceeded with the removal of children from hijra communities, despite the ambiguous attitudes of many British officials in the NWP towards the "reform" and "rescue" of such children. The removal of children occurred in the NWP in two phases: from the mid-1860s, when there was no legal framework for child removal, and under the CTA from 1871. Only fifteen children were removed from hijra households between 1865 and $1871,{ }^{133}$ whereas several children were allowed to remain with eunuchs. ${ }^{134}$ This was because removal was "not strictly legal" prior to $1871,{ }^{135}$ because few boys were found and because many British district officials were disinterested in, or opposed to, the removal of children. ${ }^{136}$

The preference of the NWP government was to appoint the biological parents of removed children as their guardian, or otherwise appoint a "respectable" Indian, usually a colonial official. However, the re-parenting of removed children presented several problems to colonial authorities. Concerns about the potential threat of moral and sexual contagion from children in hijra households were central to colonial administrative decisions about the appointment of guardians. At the same time, prospective Indian guardians-including both biological parents and Indians considered respectable - were often unwilling to take in children from hijra households due to the child's loss of caste. In the 1860s, the government sent several children to the Church Missionary Society's Sikandra Orphanage when biological parents or "respectable" Indians were unwilling to assume guardianship. The marginality of the removed children and the unwillingness of elite Indians to become their surrogate parents facilitated

\footnotetext{
130 Court quoted in Simson, "Replies," 20 Apr 1866, BL, London, IOR, P/438/62.

131 Drummond, "General Remarks," ca. 1865, BL, London, IOR, P/438/61.

132 R. Simson, Secretary, NWP, to Secretary, Government of India, 3 September 1866, BL, London, IOR, P/438/62; A.P. Howell, Under-Secretary, Government of India, to Secretary, NWP, 27 September 1866, BL, London, IOR, $\mathrm{P} / 438 / 62$.

133 In 1871, it was found that the order to remove children "was made operative in only 15 out of 61 cases." C.P. Carmichael, Inspector-General of Police, NWP, to Officiating Secretary, NWP, 29 August 1871, BL, London, IOR, P/92.

134 C.A. Elliot, Officiating Secretary, NWP, to Commissioner of Agra, 27 March 1871, BL, London, IOR, P/92; Carmichael to Sec, NWP, 29 Aug 1871, BL, London, IOR, P/92; North Western Provinces Government, 1873 NWP Judicial Proceedings, Part B Matters of Routine, July, no. 11, BL, London, IOR, P/95; Lumsden to Comm Benares, 15 Apr 1873, UPSA, Allahabad, COV/119/12.

135 Carmichael to Sec, NWP, 29 Aug 1871, BL, London, IOR, P/92.

136 Dennehy to IG Police, 15 Aug 1871, BL, London, IOR, P/92.
} 
their placement in a Christian institution, which may have been controversial in other circumstances. While colonial government child-rescue discourses were often underpinned by evangelical ideology, from the mid-1860s, missionaries themselves became involved in the project of removal.

\section{Children's stories in the colonial archive}

It is important to analyse not only the discourses and projects that surrounded nineteenth-century Indian childhoods, but also the experiences of children themselves. ${ }^{137}$ The lives of children removed from hijra communities were often characterised by multiple displacements and upheavals of orphanhood, poverty, sale by relatives, or kidnapping, and finally, of government removal. Often, removed children were treated as unwanted burdens by the colonial state, their biological relatives and other prospective guardians. The official narratives of children's lives expose the presences and silences of the colonial archive: on the one hand, the statements of kidnapped, emasculated and exploited children were emphasised in the records; on the other hand, children frequently disappeared from the records when they were no longer of interest to the colonial government, frustrating attempts to tell their stories. Above all, the colonial records obscured the agency of children, who were represented as either victims or deviant agents of corruption. Nevertheless, for colonial officials the agency of children and their potential resistance to colonial projects was a threat that necessitated ongoing police surveillance over the child following their removal. Below, I examine the stories of three children who were refused by prospective Indian guardians and sent to missionaries. ${ }^{138}$

In 1864, after a tip-off from a hijra in Mainpuri, police found two emasculated boys with a group of buggutteas, performers who "represent[ed] Hindoo deities." 139 The younger boy, Makhun, was thought to be six or seven. In a court statement - a document mediated by translation into English and the colonial legal context - Makhun told of the death of his parents and his sale by a relative:

My father and mother died, and I then went to my mother's brother in Muddoopore. One day at noon my uncle's son Murdan Singh fetched me ... and sold me to Ameera Eunuch for a handful of Rupees.... Three or four days after purchasing me, at night, Ameera and Zohura

\footnotetext{
137 As noted above, there have been several studies of nineteenth-century political and social debates about childhood, but the emphasis has generally been on constructs of childhood, rather than the experiences of children.

138 Relatively detailed records exist for eleven children removed from 1865-1871, though not all were sent to missionaries.

139 The buggutteas had "concealed the fact [of the boys' emasculation], because it would have spoilt their trade to have it known that they were employing Eunuchs to represent Hindoo deities." P.C. Dalmahoy, Superintendent of Police, Etawah, "Report on a case of kidnapping and emasculation of two boys, named Agbega and Makhun, in the Etawah district," 9 December 1865, BL, London, IOR, P/438/61.
} 
[another hijra], after worshipping, castrated me... [T] hen I was made over to the Bugguttea Koondon, in Omereyree. The Bugguttea called me Motee, and said I was a Jat. ${ }^{140}$

The colonial government removed Makhun but his surviving uncle refused to assume the child's guardianship due to his perceived loss of caste ${ }^{141}$ highlighting the position of children in the hijra community on the very margins of Indian society. In any case, according to colonial authorities, two characteristics disqualified Makhun's uncle from being an appropriate guardian: first, his son's apparent complicity in Makhun's sale to a hijra; and second, the inability of the NWP police to keep the family, who lived in Gwalior, an Indian-ruled state, under adequate police surveillance. The ongoing surveillance of Makhun was considered essential because of the perceived threat of removed children's resistance to their re-parenting. Officials proposed to send Makhun to the Sikandra Orphanage at Agra, yet there is no record of whether the orphanage accepted Makhun. ${ }^{142} \mathrm{He}$ is one of several children who disappear from the colonial record after the moment of initial government intervention, and about his future we know nothing.

In 1865, Khyratee, another child removed from a hijra household, was seven or eight. He was uncastrated and lived with "an old eunuch" named Rae. ${ }^{143}$ Rae "stated that, the boy was given to him 5 or 6 years ago by a Soldier ... belonging to some Infantry Regiment which was marching through [Aligarh] District."144 The district authorities could not find Khyratee's relatives ${ }^{145}$ and suggested an Indian considered respectable should be his guardian. ${ }^{146}$ Yet a month later, no suitable Indians had been found willing to take responsibility for Khyratee since "the inference might be drawn by natives" that he was "taken for immoral purpose." ${ }^{\prime 47}$ Having been rejected by the elite Indians of Aligarh, the Sikandra Orphanage eventually received Khyratee.

\footnotetext{
140 P.C. Dalmahoy, Superintendent of Police, Etawah, "Statement of Makhun Eunuch, 6 or 7 years old," ca. 1865, BL, London, IOR, P/438/61.

141 Dalmahoy, "Report," 9 Dec 1865, BL, London, IOR, P/438/61.

142 Ibid.; A.O. Hume, Magistrate of Etawah, to Commissioner of Agra, 14 December 1865, BL, London, IOR, P/438/61; J.H. Batten, Commissioner of Agra, to Secretary, NWP, 23 December 1865, BL, London, IOR, P/438/61; J.D. Sandford, Junior-Secretary, NWP to Inspector-General of Police, NWP, 13 January 1866, BL, London, IOR, $\mathrm{P} / 438 / 61$.

143 C. Mellor, Officiating Magistrate of Aligarh, to Commissioner of Meerut, 9 October 1865, UPSA, Allahabad, COM/9/2.

144 J.H. Prinsep, Magistrate of Aligarh, to Commissioner of Meerut, 10 November 1865, UPSA, Allahabad, $\mathrm{COM} / 9 / 2$.

145 Mellor to Comm Meerut, 9 Oct 1865, UPSA, Allahabad, COM/9/2.

146 F. Williams, Commissioner of Meerut, to Officiating Magistrate of Aligarh, 9 October 1865, UPSA, Allahabad, COM/9/2.

147 Williams to Sec, NWP, 20 Nov 1865, BL, London, IOR, P/438/62.
} 
Moola was another uncastrated youth who was placed in Sikandra. A hijra named Fyeman adopted Moola in the Upper Doab famine of 1860-61. ${ }^{148}$ Since Moola was not emasculated, authorities allowed him to continue living with Fyeman throughout the 1860s. ${ }^{149}$ However, in 1871, when Moola was fourteen, the Magistrate of Muttra became concerned: "Enquiries proved that the boy sang and danced in women's clothes, and grave suspicion arose that his [sexual] powers had been tampered with." Two doctors, Pain and Playfair, concluded "that the boy [had] frequently been used for unnatural purposes," suggesting that Moola had contagious potential. Yet considerable doubt surrounded Moola's genital development: the doctors determined Moola was "only backward in development, but still uninjured," but the Magistrate doubted this conclusion. ${ }^{150}$ The Magistrate proposed Moola should be sent to the Reformatory at the Agra Jail for two years, by which time "if he is ever to have sexual development, it will have taken place ... and all doubt will be removed." ${ }^{151}$ Yet other officials considered the location of the reformatory within a jail a significant problem, since the jail was perceived to be a sexualised environment where sodomy was rife. Since it was considered "highly advisable to remove the boy from the associations he has been accustomed to," Moola was sent to the Sikandra Orphanage. ${ }^{152}$ Hence, the defining factor in Moola's re-parenting was the perceived threat of sexual contamination he posed. In the case of all three children whose stories I have examined, placement in an orphanage was intended to stem any potential threats of moral contagion and prevent the potential resistance of the child to their removal from the hijra community through ongoing surveillance within the orphanage.

What would have these children's lives at Sikandra have been like? The missionary, the Reverend John Barton, left an account of the orphanage in the early 1860s:

On Saturday ... I witnessed one of the prettiest sights one could ever wish to behold at Secundra [Sikandra]. All the children, boys and girls, were seated in long lines ... the boys at one end, and the girls at the other... [O]ne of the boys, a little fellow ... stepped forth into the midst, and asked God's blessing, as they do every day. ${ }^{153}$

Barton's description of the orderly, godly and happy children at Sikandra, which was intended for a metropolitan missionary audience, probably deviated from

\footnotetext{
148 Mag Muttra to Comm Agra, 26 Jan 1871, BL, London, IOR, P/92.

149 Ibid.; Carmichael to Sec, NWP, 29 Aug 1871, BL, London, IOR, P/92.

150 Mag Muttra to Comm Agra, 26 Jan 1871, BL, London, IOR, P/92.

151 Ibid.

152 F.M. Lind, Commissioner of Agra, to Officiating Secretary, NWP, 6 March 1871, BL, London, IOR, P/92.

153 Mary Ann S. Barber, Sweet Childhood, and its Helpers in Heathen Lands; Being a Record of Church Missionary Work Among the Young, in Africa, the East, and Prince Rupert's Land, London: James Nisbet \& Co., 1864, p. 256.
} 
the lived experiences of children. Studies of orphanages and missionary schools have demonstrated the articulation of racial difference in these contexts. ${ }^{154}$ Karen Vallgårda has also highlighted the ideological purposes of the daily routine of mission children who: worked long hours, since labour was thought to have an inherent moral value; were made to wear uniforms to erase all signs of heathenism from their bodies; participated in physical and intellectual activities thought to inculcate appropriate gender norms; and were sometimes subjected to corporal punishment. ${ }^{155}$

The Sikandra Orphanage would have represented a very different environment than hijra households, and an entirely new set of norms of behaviour would have been enforced. Khyratee and Moola (and possibly Makhun) would have been subjected to the discipline and surveillance of the missionaries and the gendered segregation of pupils manifest spatially in straight lines. Considering the designation of gendered spaces, the missionaries would have enforced strict standards of masculine dress and normative gendered behaviour very different to the transgender hijra community. Moreover, Khyratee and Moola would have received a Christian education, and may have subsequently converted. It is probable that in this environment of clearly dichotomised gender expectations and Christian proselytising, Khyratee and Moola would have been made "ashamed" of the lives they had been brought up to in the hijra community. ${ }^{156}$ We can only guess at whether they resisted missionary expectations and norms, since both children disappear from the historical record after being accepted by the Sikandra Orphanage. ${ }^{157}$ Although the archive does not tell the stories of these boys at Sikandra, it is clear the missionary experience would have had profound effects on them, as they were inculcated with a new set of values and gendered behaviours.

\section{Removal, surveillance and the threat of children's agency under the CTA}

In 1871, the CTA provided a legal framework for the prosecution of any eunuch who "has in his charge, or keeps ... under his control" a boy under sixteen and empowered Magistrates to remove children and make arrangements for their "maintenance and education." ${ }^{158}$ The implementation of the CTA from 1871 exposed several fractures and ambiguities in government-directed projects of

\footnotetext{
154 Sen, "The orphaned colony," p. 464.

155 Vallgårda, “Adam's escape," pp. 302-07, 311.

156 Williams to Sec, NWP, 20 Nov 1865, BL, London, IOR, P/438/62.

157 Vallgårda highlights that resistance to the missionary regime was evident amongst children, but this was a "necessary failure," allowing the "fundamental difference between colonizer and colonized" to be continually reiterated. Vallgårda, "Adam's escape," pp. 310-11.

158 Act No. XXVII of 1871, BL, London, IOR, V/8/42.
} 
child rescue. First, under the CTA, the role of missionaries was relatively limited compared with the 1860s, exposing tensions within colonial projects targeting Indian children. ${ }^{159}$ Despite the evangelical leanings of many NWP district administrators, missionaries had never been a first choice as guardians for removed children, in part because placing children with missionaries stretched the limits of the official policy of religious "neutrality." Second, there were often tensions between the provincial government, which viewed the removal of children from hijra households as imperative, and British officials at the district level, who often did not regard significant interventions into hijra households and the lives of Indian children as an administrative priority or moral duty. ${ }^{160}$

From 1871, the provincial government prioritised the spatial separation of children from the hijra community through their removal and police surveillance over children's education and upbringing. The administration stressed the aim of controlling boys' bodies, preventing their emasculation and therefore causing hijras to die out. The agenda of reform was therefore deprioritised in favour of the agenda of the passive extermination of the hijra community, highlighting the limits of the government-directed child-rescue project. There is a pervading silence in the colonial archive on the fate of removed boys, which is itself revealing of government priorities. The moment of removal marks the disappearance of these (usually unnamed) boys from the colonial archive, frustrating any attempts to tell their stories beyond their separation from the hijra community.

Nevertheless, it is clear that the presence of the colonial government in these children's lives following removal largely took the form of police surveillance. Although the CTA empowered Magistrates "to make such arrangements as may be necessary for [boys'] education and maintenance," ${ }^{161}$ the NWP government did not consider this imperative. The provincial government's interest in these boys was largely confined to the prevention of contact between children and hijras by means of removal and surveillance. In contrast, details of the appointment of the new guardian and the child's care are rarely mentioned in

\footnotetext{
159 When the Act was first introduced in Gorakhpur, two boys were "made over to the Mission as no relatives were forthcoming," while a boy in Ghazipur was "made over" to a Reverend Lumsden to Comm Benares, 15 Apr 1873, UPSA, Allahabad, COV/119/12; R.L.F. McMullin, Officiating Superintendent of Police, Ghazipur, "Memo regarding 11 Minors who were said to be living with Eunuchs previous to enforcement of Act XXVII of 1871," 5 May 1873, UPSA, Allahabad, COV/119/12.

160 In several districts, British officials resisted removing children: C. Robertson, Officiating Magistrate of Mirzapur, to Commissioner of Benares, 3 November 1872, UPSA, Allahabad, COV/119/12; Amson to Comm Benares, 16 Nov 1872, UPSA, Allahabad, COV/119/12; P. Wigram, Officiating Magistrate of Basti, to Commissioner of Benares, 21 September 1872, UPSA, Allahabad, COV/119/12; R. Waddington, Superintendent of Police, Basti, to the Office of the Inspector-General of Police, NWP, 15 February 1873, UPSA, Allahabad, COV/119/12; R. Waddington, Superintendent of Police, Basti, "List of Eunuchs in the Bustee District on the 1st September 1872," ca. 1872, UPSA, Allahabad, COV/119/12.

161 Act No. XXVII of 1871, BL, London, IOR, V/8/42.
} 
the records, ${ }^{162}$ and most British officials assumed almost no responsibility for the education or welfare of children following their removal. ${ }^{163}$ Since the continued separation of the child from the deviant domestic context of the hijra household was considered crucial to the gradual extinction of the hijra community, police kept removed children, parents and guardians under surveillance. Appointed guardians also had to sign written agreements "binding" them to prevent the removed child from "return[ing] to his old associates." ${ }^{164}$

The NWP government's preoccupation with ensuring the spatial separation of hijras and children through surveillance is evidence of the perceived threat of these children's agency. The colonial government was not only concerned that hijras might attempt to maintain their ties to these children - or in the idiom of colonial officials, "entice" children back to the hijra communitybut also that children might return to hijras of their own accord. Written agreements between the government and new guardians acknowledged that the child in question might want to "return to his old associates" and would need to be forcibly prevented by a combination of parental and state power. Although colonial administrators read the wilfulness of removed children as evidence of their deviance and corruption and of the coercive power of the hijra-child relationship, the need to spatially separate children and eunuchs is perhaps evidence that these relationships could have affective aspects. Despite colonial discourses of victimisation surrounding children removed from hijra households, the resistance of removed children threatened to undermine the colonial project of the gradual extinction of the hijra community.

The colonial government did not succeed in passively exterminating hijras as a social category, in part because of hijra resistance to the CTA. Hijras are still a presence in north Indian society, though they are highly marginalised and stigmatised. Whereas hijra domesticities were the focus of colonial moral panic and experimental child rescue interventions, the domestic sphere and everyday life were also important sites of hijra resistance.

To evade the prohibition of performance and cross-dressing with decreased risk of prosecution, hijras sang, danced and wore feminine clothing in hijra households, away from the gaze of the police. On several occasions, police found musical instruments and feminine clothing in hijra households, suggesting

162 This was reflected in the classificatory system adopted for the annual reports, which required information on the "Presence of boys under 16, with eunuchs," Hobart to Off IG Police, NWP, 28 Jun 1876, $\mathrm{BL}$, London, IOR, $\mathrm{P} / 839$.

163 The annual reports mention a rare case of two "emasculated youth of ten years' age" in Basti in 1877, in which a Magistrate "promised to endeavor to procure for [boys] some means of honest livelihood," R.T. Hobart, Deputy Inspector-General of Police, NWP\&O, to Inspector-General of Police, NWP\&O, 11 September 1877, BL, London, IOR, P/840.

164 C.P. Carmichael, Officiating Commissioner of Benares, to Inspector-General of Police, NWP, 24 March 1875, UPSA, Allahabad, COV/119/12. 
hijras "secretly" performed in "private" locations. ${ }^{165}$ Hijras also resisted colonial intervention in guru-chela relationships. Whereas a chosen chela would inherit their guru's share of property upon their death, the CTA prohibited the making of wills and introduced property registers. Consequently, hijras hid moveable property from the police to resist colonial interference in hijra inheritance patterns and guru-chela succession. ${ }^{166}$ Hijras also continued to ask for alms from householders following births and thereby enacted their power over fertility as infertile persons and their somewhat paradoxical links to reproductive sexualities on an everyday basis. ${ }^{167}$ Moreover, daily ritual practices in shrines and hijra households, in which hijras kept images of particular deities, evoked their mythology and the divine sanction of hijra existence, and thereby legitimised the hijra community in the face of criminalisation. ${ }^{168}$ Thus, the domestic and quotidian were not only sites of colonial intervention, but also of hijra agency and resistance. The anticipated "gradual expiration of the eunuch class"169 did not eventuate, and the hijra survived as a socio-cultural role.

\section{Conclusion}

In the 1860s, British colonial officials characterised hijra households and kothas as environments in which children were sexually "corrupted" - as "deviant" domesticities. Several aspects of these domestic formations concerned officials, including: extra-procreative and non-procreative sexualities; the apparent absence of conjugal domesticity; and the inability to know and record transparently these domestic spaces. In particular, the blurred lines between non-biological kinship, biological kinship and various relationships of dependence were the subject of colonial anxiety. The domestic arrangements of both hijras and women labelled "prostitutes" commonly featured constructed kinship that included adoption, de facto kinship or treating a person as a relative, and the discursive deployment of kinship terminology. Forms of kinship-making and hierarchical relationships (such as guru-chela structures) were criticised as coercive and criminal relationships. Colonial discussion of, and projects targeting, these "deviant" forms of domesticity are part of the

\footnotetext{
165 E. Tyrwhitt, Inspector-General of Police, NWP\&O, to Secretary, NWP\&O, 28 May 1878, BL, London, IOR, P/1138; Smith to IG Police, NWP\&O, 6 Jul 1881, BL, London, IOR, P/1614.

166 Smith to IG Police, NWP\&O, 6 Jul 1881, BL, London, IOR, P/1614; O.L. Smith, Deputy InspectorGeneral of Police, NWP\&O, to Officiating Inspector-General of Police, NWP\&O, 15 May 1882, BL, London, IOR, P/1816.

167 Oldham to Comm Benares, 6 Feb 1875, UPSA, Allahabad, COV/119/12.

168 Shortt, "The Kojahs of southern India," p. 403; Enthoven, The Tribes and Castes, p. 228; R. Annesley, Officiating Superintendent of Police, Benares, to Magistrate of Benares, 12 April 1873, UPSA, Allahabad, $\operatorname{COV} / 119 / 12$.

169 E. Tyrwhitt, Inspector-General of Police, NWP\&O, to Secretary, NWP\&O, 17 September 1877, BL, London, IOR, P/840. See also Berrill to IG Police, NWP\&O, 1 May 1896, UPSA, Allahabad, COA/18/5.
} 
broader history of the marginalisation and criminalisation of certain indigenous domestic formations by both the colonial government and the upper echelons of Indian society in the nineteenth century.

However, the colonial project to rescue children from deviant domestic spaces was fractured and limited. Despite rhetoric of the need to save children in kothas and hijra households, which was often underpinned by Christian ideology, missionary-government cooperation was circumscribed in practice. Moreover, although evangelical belief was particularly influential in the North-Western Provinces administration, many British administrators at the district level did not share this evangelical outlook and viewed the rescue of Indian children as neither a moral imperative, nor an achievable goal. In practice, the removal and reform of children was limited. Not only did the NWP government's proposal to save girls from prostitution fail, it transmuted into a discussion of how best to protect the male clients of girl prostitutes. Thus, the rhetoric of child rescue had tenuous influence on colonial officials in the face of the pragmatics of colonial rule and masculine sexual privilege. Although the removal of children from hijra communities was enshrined in law in 1871 under the CTA, the NWP government deprioritised the stated aim of reforming removed children and gave little attention to the education and upbringing of removed children. Instead, government policy called for the continued spatial separation of children from the hijra community through forced removal and ongoing surveillance in order to prevent emasculation and, therefore, the reproduction of hijra bodies. The agenda of passive extermination was prioritised over the agenda of reform.

The presences and silences of the colonial records make the narration of removed children's lives a difficult task for the historian. Children appear in the archive as either a contaminating force, or as victims. Yet the colonial archives contain fragments of these children's lives and their agency. The resistance of children to their removal and re-parenting was rendered in the colonial records as evidence of the criminality and sexual corruption of children in the hijra community. However, the concerns that children would return to hijras demonstrate that the agency of children to act against parental and state authority threatened to undermine the colonial agenda of causing the hijra community to "die out." In the space between the colonial tropes of victimhood and criminality, lie hints of a story of the wilfulness and agency of these marginalised children.

\section{Acknowledgements}

This chapter has benefitted enormously from the comments of a number of people who have read its various incarnations, including Margaret Jolly, Peter Jackson, Robin Jeffrey and Assa Doron. Hyaeweol Choi, Carolyn Strange, Kalpana Ram 


\section{Deviant Domesticities and Sexualised Childhoods}

and many other contributors to this volume gave insightful comments at the Paradoxes of Domesticity conference and at other seminars at The Australian National University. Thanks also to Carolyn Brewer for her close reading and edits of the chapter. 
This text taken from Divine Domesticities: Christian paradoxes in Asia and the Pacific, edited by Hyaeweol Choi and Margaret Jolly, published 2014 by ANU Press, The Australian National University, Canberra, Australia. 